\title{
Uma visão sobre a interpretação das canções amazônicas de Waldemar Henrique
}

MÁRCIA JORGE ALIVERTI

$\mathrm{E}$ STE TEXTO apresenta uma análise musicológica, voltada para a interpretação da música regional da Amazônia. O estudo foi dirigido para a obra de Waldemar Henrique (Belém, 1910-1990), compositor paraense de grande relevância, que mereceu o reconhecimento da crítica especializada pela alta qualidade de suas composições e pela maneira sensível com que retratou a Amazônia.

As canções de temática regional escolhidas já foram editadas e são de fácil acesso ao público. São elas: "Foi Bôto, Sinhá!”, “Cobra-Grande”, “Tamba-Tajá”, "Matintaperêra”, "Uirapuru”, “Curupira” e "Manha-Nungára”.

\section{"Foi Bôto, Sinhá!"}

\section{A lenda do Boto}

Em noite de festa à beira do rio, o boto transforma-se em um belo rapaz, que se veste todo de branco e usa sempre um chapéu, também branco, na cabeça. Esse chapéu nunca é retirado, pois serve para esconder o orifício que tem na testa e usa para respirar. Não se sabe por que esse orifício não desaparece na sua transformação. Bonito e elegante, o rapaz é bom dançarino e bebedor. Conquista facilmente as moças jovens e bonitas, casadas ou não. Na festa, dança e namora. Depois, convida a namorada para um passeio, para seduzi-la. Seu poder de sedução é incrível, hipnótico. Muitas de suas vítimas foram "salvas" no último momento porque alguém gritou, fez barulho e as tirou do transe. Após o envolvimento sensual, o boto atira-se no rio e volta à sua forma animal. A namorada, encantada, fica triste. Muitas vezes adoece e acaba por se atirar ao rio à procura do seu amado. As que resistem ao suicídio acabam por parir uma criança, que pode ser boto, já nascer na forma de peixe ou ser normal. Muitas são as histórias de parteiras que viram nascer peixes do ventre dessas jovens. Se nascer uma criança, a mãe a banha no rio para ver se o filho se transforma ou não em boto. Também há os casos de crianças que, se colocadas no rio, já saem nadando.

\section{Texto da Canção - Versos de Antônio Tavernard ${ }^{1}$}

1. Tajá-Panema chorou no terreiro,/2. E a virgem morena fugiu no costeiro. (bis)/3. Foi Bôto, Sinhá.../4. Foi Bôto, Sinhô!/5. Que veio tentá/6. E a moça levou/7. No tar dansará,/ 8. Aquele doutô,/9. Foi Bôto, Sinhá.../10. Foi Bôto, Sinhô!/ Tajá-Panema se poz a chorá./ 11. Quem tem filha moça é 
bom vigiá! (bis)/ 12. O Bôto não dorme/ 13. No fundo do rio/ 14. Seu dom é enorme/ 15. Quem quer que o viu/ 16. Que diga, que informe/ 17. Se the resistiu/ 18. O Bôto não dorme/ 19. No fundo do rio...

\section{Análise do texto}

O texto é baseado em um mito bastante conhecido na região amazônica.

Inúmeras são as histórias contadas com a veracidade característica dos "cabôcos"2. O Boto é a saída social para as moças que engravidam sem casar. Desculpa fundamental que desvia a jovem do papel de pecadora para o de vítima. O mito também serve ao rapaz que engravidou uma jovem, uma vez que não será procurado, nem identificado, nem responsabilizado. Como resolve tantos "desconfortos", o Boto apresenta-se como um mito socialmente perfeito, sendo talvez esta a razão que o mantém tão vivo até hoje.

O texto tem palavras de uso regional que precisam ser identificadas e ter seu significado aclarado. São elas:

- Tajá-Panema (verso 1): tajá: planta de folhas grandes e sem flor, muito comum e variada na Amazônia; panema: palavra indígena para tristeza. $\mathrm{O}$ Tajá-Panema é uma variedade de Tajá que "chora", pois expele gotas de líquido de suas folhas. Segundo o povo da região, esse fenômeno dá-se como prenúncio de uma desgraça ou acontecimento triste.

- Costeiro (verso 2): barco que percorre a orla dos rios.

- Tar (verso 7): tal. Escrito com $r$ no final para imitar a maneira "cabôca" de falar. É comum a troca do $l$ pelo $r$ no final de palavras.

- Dansará (verso 7): dançaral, local descampado, reservado às festas ribeirinhas. É onde o Boto costuma aparecer para seduzir as moças.

- Dom (verso 15): referente ao poder de encantamento do Boto e/ ou ao membro viril.

O texto marca a presença de características do falar da região amazônica, o que também deve ser observado pelo intérprete. São elas: corte do $r$ no final das palavras: "doutô" e "Sinhô"; troca do $s$ pelo $r$ na palavra: "tar"; corte do $r$ final dos verbos no infinitivo: "tentá" (tentar), "chorá" (chorar) e "vigiá" (vigiar); colocação do $u$ no lugar do $o$ em final de palavras: rio = "riu", que rima com resistiu; uso do pronome pessoal reto tu.

Há uma característica regional que devemos observar: o uso do $s$ chiado. Na região Norte o s só é sibilante no começo de palavra. Ao final nunca, pois isso é para os falantes da Amazônia uma característica de outras regiões. Exemplos: mas = " "mach", mesmo = "mechmo", lesma = "lechma".

Não há variação de foco narrativo no texto. Mesmo assim, o contador da história dirige-se a pessoas diferentes (Sinhá e Sinhô), o que ajuda no direcionamento cênico.

\section{Aspectos musicais}

A canção "Foi Bôto, Sinhá!" foi composta em 1933 e dura 2’25" ca. Seu texto é completamente silábico. Foi escrita originalmente em Ré menor (tonalida- 
de muito utilizada pelo autor) e possui tessitura muito confortável: uma oitava a partir do Ré central do piano ${ }^{3}$. Tecnicamente não oferece dificuldades de espécie alguma. Esse conjunto de características facilita a boa pronúncia do cantor e, conseqüentemente, uma melhor compreensão do texto por parte do ouvinte. Porém, essa facilidade exige mais de nossa dicção, pois o texto precisa ser bem pronunciado, sem artificialismos que dificultem sua compreensão. O texto é soberano quando se conta uma história e, no caso de Waldemar Henrique, o texto é tratado com maestria, pois o compositor coloca toda a partitura a seu serviço, como veremos a seguir. É preciso analisar o teor do texto e informar-se sobre sua contextualização regional para que não se corra o risco de despir a canção de sua dramaticidade.

A canção traz como tema uma lenda cuja importância para a sociedade ribeirinha ${ }^{4}$ é, ainda hoje, altamente pertinente, porque ainda é viva. O conhecimento desse fato é fundamental para a compreensão do caráter dramático da narração, o que pode nos ajudar a escolher a linha de condução da música.

A canção não apresenta mudança de tonalidade no decorrer da obra, mas traz alterações na mão direita do piano (compassos 9, 11, 13 e 15), que funcionam como cromatismos expressivos. Essas alterações dão o clima de sensualidade e mistério que envolve o sumiço da virgem (ver texto poético e lenda).

"Foi Bôto, Sinhá!" é uma canção estrófica dividida da seguinte forma:

- Introdução: o primeiro compasso, repetido por três vezes, tem a função de preparar o ouvinte para o discurso. Aqui, já devemos estar com nossa expressão facial preparada, e podemos conduzir gestos e olhares para chamar a atenção do público para a gravidade da narração que irá iniciar.

- Seção A: do compasso 4 ao 9 com repetição. Como toda repetição, pede uma diferenciação de execução do trecho, que pode ser feita por meio da exploração das nuances interpretativas, de timbre e / ou dinâmica, para le-var o público a ouvir com interesse a mesma mensagem em uma nova "roupagem".

- Seção B: do compasso 9 (casa 2) ao compasso 17. A melodia torna-se mais sensual com a figuração rítmica mais fluida e com os cromatismos, e a canção atinge seu clímax com a constatação do fato de que foi o Boto quem seduziu e levou a moça. Essa seção merece um destaque especial que pode ser dado pela dinâmica e que ponha em relevo o clímax da narrativa, no qual o compositor apresenta dramaticamente a constatação da fatalidade.

- Coda - Casa 1: da metade do primeiro tempo do compasso 17 ao primeiro tempo do compasso 21. Aí temos um Da Capo para que a segunda estrofe possa ser levada com a melodia da seção A. Saímos lentamente do clímax e diminuímos a intensidade sonora e a densidade interpretativa, para iniciar novamente a caminhada tensa da segunda parte do discurso.

- Casa 2: do segundo tempo do compasso 21 ao fim. Aqui, não estamos mais emitindo som algum, mas a interpretação continua e não podemos deixar morrer a dramaticidade da nossa expressão, pois a canção ainda não acabou. Nossa postura e face devem manter-se dentro do contexto grave da peça, até que a última nota do piano desapareça. 
A estrutura da canção é muito simples, mas causa impressão marcante. $\mathrm{Na}$ linha melódica, predominam os intervalos de $2^{\underline{a}}$ e $3^{\underline{a}}$ (compassos 2 ao 5,7 ao 9 , 11 ao 22), aparecendo apenas um salto de $4^{\underline{a}}$ no compasso 10 e um de $6^{\underline{a}}$ no compasso 6. Os intervalos menores se mantêm na maioria dos compassos, mas a tônica insistente, constante, aparece em quase todos os acordes do baixo, com exceção do segundo tempo dos compassos 3,5 e 6 e do compasso 7 .

Apesar de a tônica não estar presente nesses momentos, a célula rítmica principal que vemos nos compassos $2,4,8,9,11$ e 13 , e uma variante simples não desaparecem em momento algum. Essa "batida" é como um toque de tambor solene e constante, como o de uma marcha fúnebre. Isso faz com que se crie a atmosfera pesada e densa na música, que nos guiará na escolha do andamento, que não é indicado pelo compositor. Podemos considerar essa repetição rítmica como um gesto musical descritivo. A acentuação dessa "batida" está presente em muitas danças características da região, notadamente na parte lenta da dança do "siriá" $5^{5}$. As acentuações da dança e a da canção são iguais. Isso marca a relação entre a tragédia e a sensualidade. Não podemos deixar nenhum desses dois aspectos de lado. A marcha fúnebre aqui tem seu "gingado", como quase tudo na vida do "cabôco".

A estrutura musical está em contato constante com a estrutura do texto. Os elementos musicais reforçam nitidamente aspectos da poesia. Os silêncios (pausas) foram usados sempre na sua função construtiva ${ }^{6}$. Têm função temporal na construção da célula rítmica constante em toda a peça na mão esquerda da parte do piano e função rítmica ao anteceder a melodia da mão direita do piano nos compassos de 9 a 15. Neste trecho (9 a 15), também encontramos gestos musicais dramáticos integrados à narração dos fatos.

Na seção B, que funciona como refrão, o texto confirma a atuação do Boto sobre a jovem e as figuras se aceleram, aparecem as melodias na mão direita do piano, marcando a sensualidade e o aumento de tensão. Essa tensão terminará por diluir-se com o fatalismo das repetições constantes do intervalo de terça do compasso 17 até o fim, no canto e no acompanhamento. Temos também a indicação de accelerando (compasso 17) e rallentando (compasso 20), que nos reportam a nuances dessa tensão. O intérprete poderá envolver completamente seu público se tirar partido desse jogo de tensões, traduzindo-o para a sua linguagem vocal, gestual e timbrística. Como já dissemos antes, o intérprete não deve deixar morrer a dramaticidade até a última nota. O som decresce, mas o caráter permanece.

O compositor dá várias indicações de intensidade e alterações de andamento na partitura. São elas: Crescendo (sinal) - compassos l e 13; Diminuendo (sinal) - compassos 1, 7, 9, 10, 11, 14, 15, 18, 19 e 23; Diminuindo (escrito em português) - compasso 7; Accelerando - compasso 17; Morrendo (escrito em português) - compassos 19 e 22; Rallentando - compasso 20; Fermata - compasso 24. 


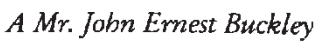 \\ Foi Bôto, Sinhá! \\ Toada amazônica}

Lenda Amazônica No 1

(1933)

Versos de Antonio Tavernard

Waldemar Henrique (1905 - 1995)
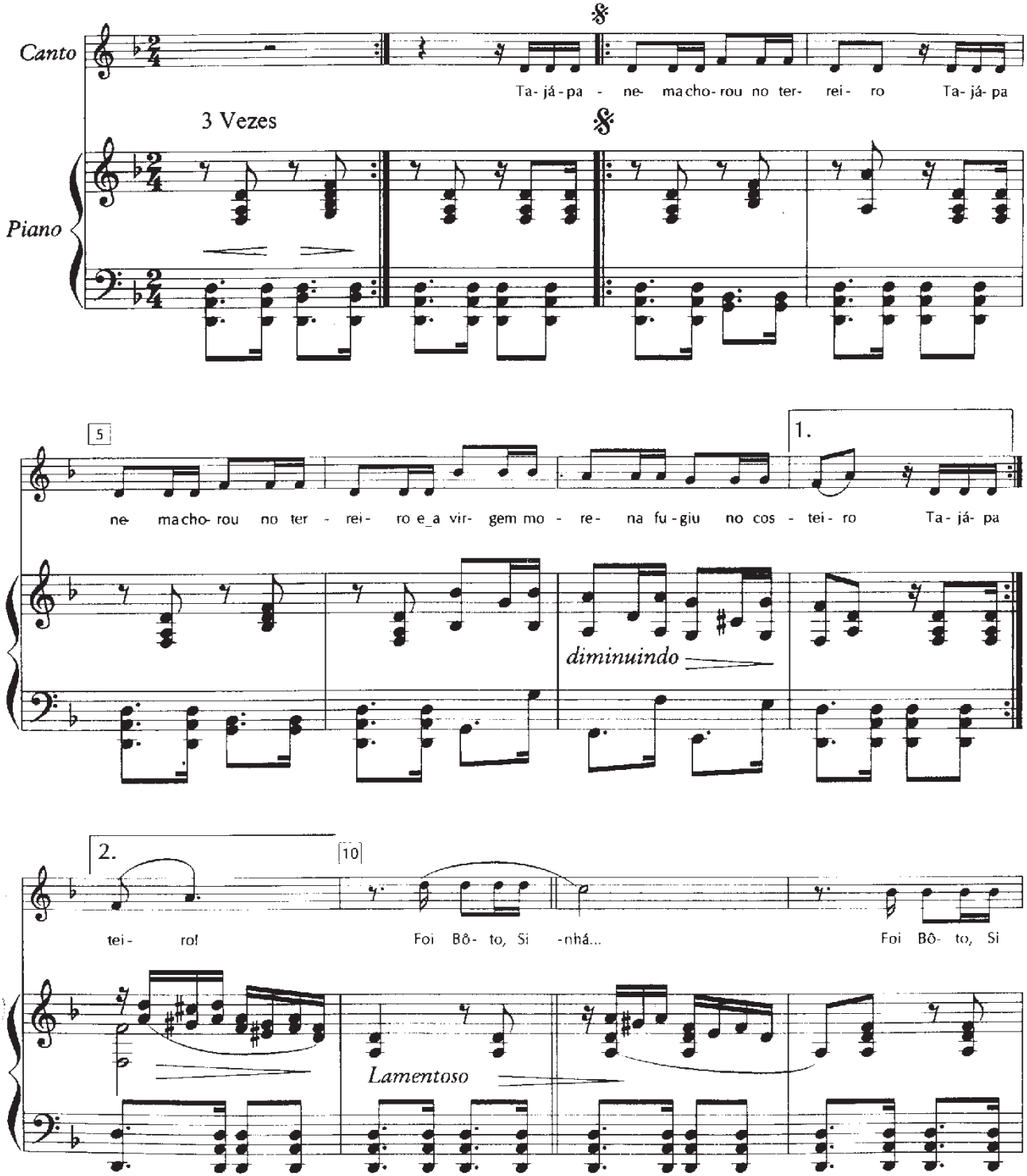

Composto graficamente em maio de 1995, pela Furdaçẫo Carlos Gomes (Belém - Pará - Brasil)

Temos também a indicação expressiva: Lamentoso, no compasso 10. Todas essas indicações são coerentes, porque foram colocadas pelo compositor de acordo com a tensão e relaxamento harmônicos e/ou do texto, auxiliando a música a caminhar de acordo com o seu conteúdo. Servem de base para a construção da nossa interpretação. 
1i5

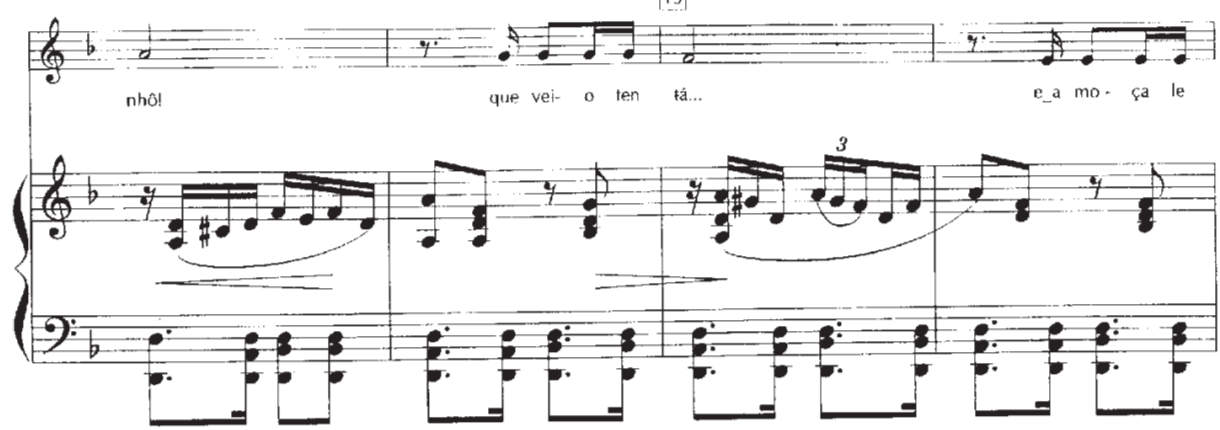

$[20]$
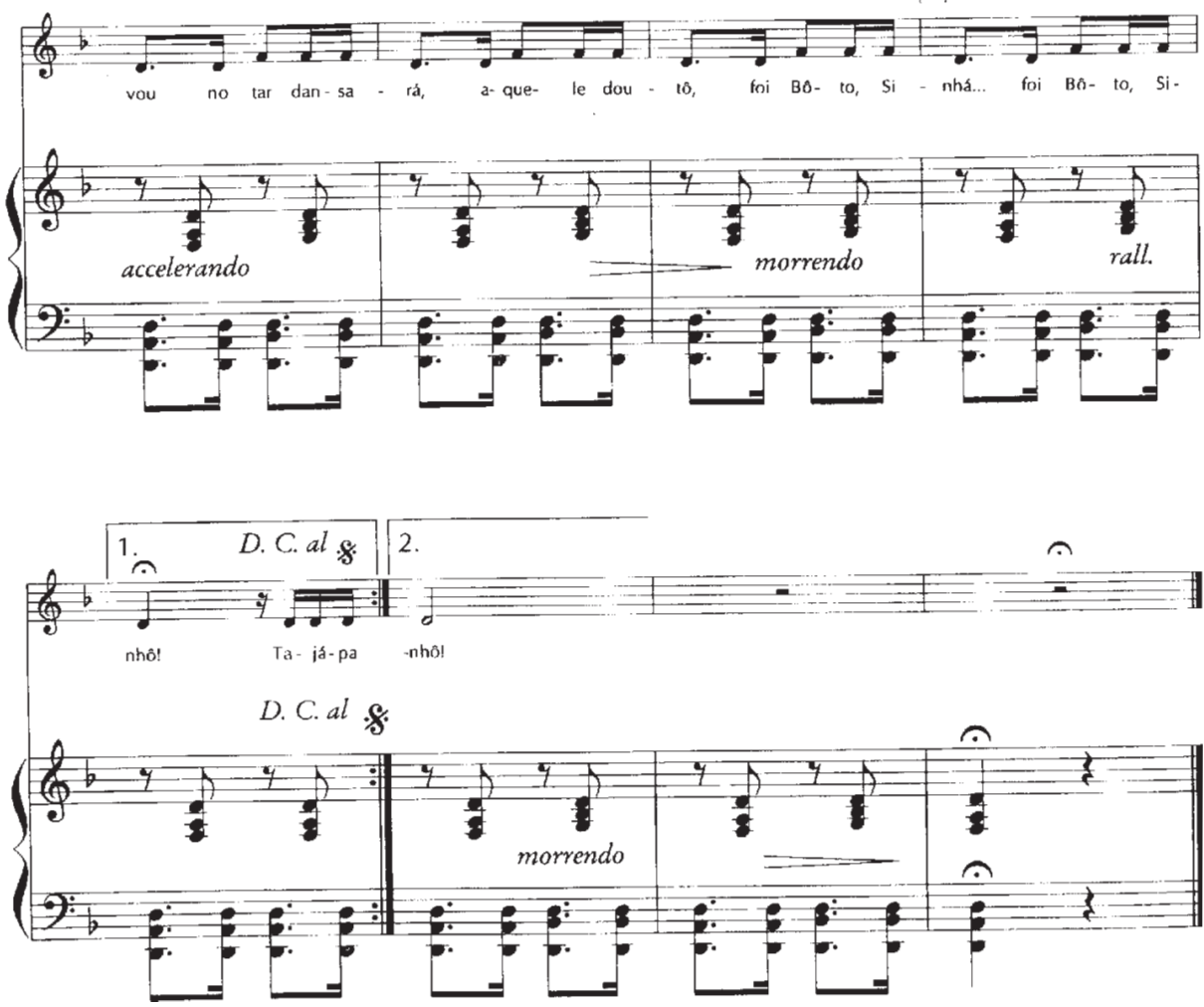

Partituras de canção amazônica Foi Bôto, Sinhá!

\section{Cobra-Grande}

\section{A lenda da Cobra-Grande}

A Cobra-Grande, Boiúna ou Boiaçu ${ }^{7}$ é uma cobra de proporções gigantescas. Pode ser escura, ou, segundo alguns, ter as cores vermelha, preta e amarela. Seus olhos, fora da água, têm uma luz própria, forte e brilhante, que hipnotiza e paralisa suas vítimas e desnorteia os navegantes. Do seu rastro fundo no chão surgem os rios e igarapés. Seu apetite é voraz e, além de atacar em terra, faz virar canoas e até barcos grandes, a fim de devorar seus passageiros e tripulantes. Matá-la atrai desgraça e ruína. Quem a vê fica cego, quem a ouve fica surdo e 
quem a segue fica louco. Muitos que a viram voltaram mudos, com febre e assombrados. Não existe nela nada da sensualidade de tantos outros mitos. Não se transforma em homem ou mulher, não seduz, não ajuda. Ataca sempre para matar. Também é mágica. Transforma-se em navio, vapor ou canoa, e quando sente a aproximação de outra embarcação, voa e desaparece. Pode fazer o barulho de um motor de barco ou ser silenciosa como todo réptil. Nas águas, parece um imenso tronco de árvore a boiar na superfície.

\section{Texto da canção - Versos de Waldemar Henrique ${ }^{8}$}

1. Crédo! Cruz!/2. Lá vem a Cobra-Grande,/3. Lá vem a Boi-Una de prata!/4. A danada vem rente à beira do rio.../ 5. E o vento grita alto no meio da mata!/ 6. Crédo! Cruz!/ 7. Cunhantã te esconde/8. Lá vem a Cobra-Grande/ 9. Á-á.../ 10. Faz depressa uma oração/ 11. P'ra ela não te pegar/ 12. Áá.../ 13. A floresta tremeu quando ela saiu.../ 14. Quem estava lá perto de medo fugiu/ 15. E a Boi-Una passou logo tão depressa,/ 16. Que somente o clarão foi que se viu.../ 17. Cunhantã te esconde, etc.../ 18. A noiva Cunhantã está dormindo medrosa,/ 19. Agarrada com força no punho da rêde,/20. E o luar faz mortalha em cima dela,/21. Pela fresta quebrada da janela.../ 22. Êh Cobragrande/23. Lá vai ela...

\section{Análise do texto}

O texto narra sinteticamente uma história dramática. O medo é, portanto, muito menos fantasioso do que se pensa e devemos estar conscientes disso. Esse medo está marcado desde o início nos versos 1 e 6, quando o narrador esconjura a cobra; no verso 7 , quando exorta a moça a fugir; nos versos 10 e 11 , quando o narrador aconselha que seja pedida a proteção divina; no verso 14, que diz que todos fugiram de medo; e, finalmente, no verso 17 , pois a moça não dormia em paz. Não podemos esquecer os versos 9 e 12, que só trazem o á-á, aqui usada como expressão de temor. A sensação de impotência contra a fera é clara, pois até a "floresta tremeu quando ela saiu" (verso 13) e o luar, que, clareando a figura da jovem, revela à cobra onde está a presa, é considerado como uma mortalha. Não há como escapar da fatalidade. A boi-úna tem muitas armas. É rápida (verso 15) e silenciosa (verso 16). O clarão mencionado nesse verso é a luz hipnótica que sai dos olhos da cobra e que paralisa suas vítimas.

Apesar de ser muito regional como tema, há nos versos apenas duas palavras regionais: Cunhantã (versos 7 e 17) - moça e Boiúna (versos 3 e 15) - cobragrande. Como características do falar "cabôco" do Norte, temos: o uso corrente das palavras de origem indígena (cunhantã e boiúna); o uso da palavra composta: cobra-grande, para referimento à boiúna; o uso do pronome pessoal reto tu.

Há uma variação de foco narrativo no texto, quando o narrador se dirige à cunhantã e nós podemos tirar partido dele para uma alteração de timbre, dinâmica ou direcionamento corporal. Também podemos considerar que o narrador fala ora para si mesmo, ora para um ouvinte da história (por exemplo, verso 22). Cabe-nos decidir se isso será relevante para nossa concepção cênica. 


\section{Aspectos musicais}

A canção "Cobra-Grande", de 1934, dura ca. de 2' e traz indicação de andamento Lento. Foi escrita em Ré menor e é harmonicamente mais elaborada que a canção anterior. $\mathrm{O}$ compositor inicia a peça com um compasso introdutório no qual, apesar da tônica sustentada na mão esquerda da parte do piano, temos uma politonalidade na mão direita. O efeito sonoro é interessante e mostra logo o caráter da peça, tendo o compositor escrito na partitura "misteriosamente" (compasso 1) e "com temôr" (pausa que antecede a entrada do canto). Essas indicações e a harmonia sugestiva dão-nos uma boa base para a concepção interpretativa. Temos ainda outras indicações do compositor sobre expressão: "Brusco" - compassos 3 e 25; "Assombrado" - compasso 11; "Com expressão" compasso 14. Todas as indicações são altamente coerentes com a mensagem do texto e o compositor nos dá o direcionamento da interpretação.

Também contamos com muitas indicações de dinâmica, igualmente coerentes, embora não haja dinâmica escrita no primeiro compasso: Crescendo (sinal) compassos 2, 4, 9, 12, 15-16, 17 e 18; Decrescendo (sinal) - compassos 2, 5, 13 e 21 (duas vezes); Forte (sinal) - compassos 7, 9 e 25; Piano (sinal) - compasso 9. O compositor também faz alterações significativas de andamento para explorar ainda mais a expressividade da mensagem: Rallentando - compassos 9 e 20; Allargando - compassos 12 e 18; Fermatas - compassos 2, 6, 11, 14, 18, 20, 22, $23,24,25$ e 26. Temos, assim, vários sinais expressivos a seguir. Essas indicações, aliadas aos desvios do foco narrativo, ajudam-nos a explorar diferentes timbres vocais.

O texto, predominantemente silábico, apresenta outra ocasião boa para diferenciação de timbre no compasso 12 , que se repete quatro vezes na execução da obra e tem uma pequena vocalização sobre duas notas com a vogal $a$. Não devemos fazê-la sem pensar na sua ligação com o texto, pois é uma clara expressão de temor e uma característica do falar do cabôco amazônico.

Encontramos um cromatismo no compasso 19, de ordem expressiva. Contudo, nos compassos 1, 3 e 25, o uso da politonalidade na mão direita do pianista dá-nos uma impressão cromática interessante. Um recurso que soa exótico aos nossos ouvidos e transmite sensação de mistério e medo, como queria o compositor.

A canção é estrófica e está assim dividida:

- Introdução: do compasso 1 à metade do 11 . Aqui, o texto descreve a paisagem e prepara o público para a cena dramática. O texto é claramente descritivo e podemos tirar muito partido disso.

- Seção A: metade do compasso 11 à metade do compasso 14 . O foco narrativo desvia-se para a vítima da cobra-grande, a cunhantã. Temos novamente a oportunidade de redirecionar nossa gestualidade.

- Seção B: metade do compasso 14 até o 23. Outra mudança de foco narrativo, com uma descrição grandiosa do cenário. A cada mudança de foco, novas oportunidades de enriquecimento interpretativo abrem-se para nós. 
- Coda: compasso 24 ao 26. O intérprete não pode deixar de causar impacto no público com esse final profundamente teatral, pensado e medido para amedrontar.

Toda a estrutura da obra mantém sabiamente um profundo contato com a estrutura do texto. Cada seção da música corresponde a partes distintas do texto. O compositor usa muitos elementos estruturais para reforçar esses aspectos. A politonalidade que é usada na introdução volta triunfal no último compasso; a harmonia se adensa nos momentos de maior dramaticidade, como nos compassos 9 e 10 e de 19 a 24 . Há uma economia de saltos na linha do canto que facilita a clareza da narrativa. Muitas fermatas ajudam a manter o clima de suspense e mistério da canção e os movimentos bruscos que se seguem a elas, indicados pelo autor, dão um movimento assustador à melodia.

A mencionada economia de saltos da linha melódica tem como salto máximo uma $7^{\underline{a}}$, que acontece apenas uma vez (antes da coda). O salto de $6^{\underline{a}}$ também acontece apenas uma vez (compasso 15 para 16). Já o de $5^{a}$, cinco vezes (compassos 3 para 4, 6 para 7, 9 para 10, 11 e 12 para 13. O restante todo é feito de saltos de $2^{\underline{a}}$ e $3 \underline{a}$. A extensão é a mesma da canção anteriormente analisada, “Foi Bôto, Sinhá!". Uma oitava a partir do Ré central do piano. Muito confortável e, desta vez, o compositor reservou a nota mais aguda para o final. Que maravilha para nós, podermos executar, no final de nossa performance, uma nota que parecerá tão aguda, mas será feita com toda a tranqüilidade! Eis aqui uma ótima oportunidade para a exibir de dotes vocais sem perigo algum.

Não existem dificuldades de emissão, extensão, ritmo ou saltos. Mas é preciso conhecer muito bem o teor do texto e "contar" a história com veemência e excelente dicção, sem arroubos líricos que dificultem a compreensão do texto para dar o devido caráter à peça. Existe uma íntima relação do texto com a maneira sincera e viva com que os cabôcos contam suas histórias. Muitos gestos, olhares e direcionamento cênico podem ser utilizados, sempre aliados ao bom gosto, é claro.

Nessa canção, o som e o silêncio têm igual importância. Existem muitos silêncios preparatórios que, se respeitados, imprimem especial suspense à peça. Podemos observá-los nos compassos 2, 4, 5 (com marcação especial na parte do piano), 19, 20 e 23 e 24 (após as fermatas). No compasso 10, a pausa tem função transformadora, pois auxilia o discurso a sair da descrição da cena para a conjuração pessoal do interlocutor. Os sons descrevem paisagem, emoções, sensações, e estão perfeitamente ligados à narrativa dos fatos.

\section{Tamba-Tajá}

\section{A lenda do Tamba-Tajá}

Na tribo dos índios macuxis havia um índio que, por muito amar sua esposa, levava-a sempre consigo para todo lugar, fosse para caçar, pescar ou lutar. Certa vez, o índio teve que ir para a guerra, mas a esposa ficou doente, sem 
poder andar. Não querendo separar-se de sua amada, ele fez um saco com folhas de bananeira, para poder carregá-la nas costas. Durante o combate, sua amada foi ferida e morreu. O índio, desesperado de amor, enterrou-se junto com ela. No lugar onde jaziam seus corpos, nasceu um tajá ${ }^{9}$ diferente, pois atrás de cada grande folha verde da planta nascia grudada uma pequena folha de forma vaginal. Renasciam assim os amantes, unidos novamente para sempre.

\section{Texto da canção - Versos de Waldemar Henrique ${ }^{10}$}

1. Tamba-Tajá/2. Me faz feliz,/ 3. Que meu amor me queira bem.../4. Que seu amor seja só meu,/5. De mais ninguém,/6. Que seja meu,/7. Todinho meu,/ 8. De mais ninguém.../9. Tamba-Tajá,/ 10. Me faz feliz/ 11. Assim o índio carregou sua "macuxy" / 12. Para o roçado, para a guerra, para a morte.../ 13. Assim carregue o nosso amor a boa sorte.../ 14. Tamba-Tajá.../ 15. TambaTajá,/ 16. Me faz feliz,/ 17. Que mais ninguém possa beijar o que beijei,/18. Que mais ninguém escute aquilo que escutei/ 19. Nem possa olhar dentro dos olhos que olhei/ 20. Tamba-Tajá...

\section{Análise do texto}

O texto foi escrito especialmente para a peça e trata de um mito amazônico: o Tajá. As plantas têm na Amazônia poderes curativos e mágicos, conhecidos pelos pajés e feiticeiros. O Tamba-Tajá tem a propriedade especial de proteger os amantes. É por isso que a pessoa que canta se dirige a ele fazendo um pedido, uma espécie de prece pagã, que não é menos desprovida de fé que uma prece religiosa, pois os cabôcos acreditam piamente no poder das plantas. Desse modo, devemos revestir de uma certa religiosidade sua execução.

Existem no texto poucas palavras de uso regional:

- Tamba-tajá (versos $1,9,14,15,16,21$ e 22) - de tambá - concha e tajá planta também conhecida em outras regiões como tinhorão. O Tamba-tajá é constituído de grandes folhas em forma de coração, que têm cor verde escura e com uma pequena folha em forma vaginal grudada atrás de cada uma das folhas grandes.

- Macuxi (verso 11) - mulher da tribo dos índios macuxis.

- No texto, há pouca presença de características do falar da região. Temos: o uso do pronome pessoal reto tu e a pronúncia do $s$ chiado no final das palavras. Fica assim o regionalismo do texto mais por conta da atitude descrita nos versos que pelo falar regional reproduzido. Não há variação de foco narrativo no texto, no qual o narrador dirige-se todo o tempo ao tamba-tajá, e devemos estar atentos para esse fato, para não adotarmos desvios de postura e gestualidade fora do contexto.

\section{Aspectos musicais}

A música foi escrita em 1934, na tonalidade de Lá b Maior e tem duração de aproximadamente 3'. Sua extensão é confortável e vai do Dó central ao Ré, uma oitava acima. Seu texto é totalmente silábico. 
Essa canção tem uma característica muito especial: toda a linha do canto, na primeira parte (compassos de 5 a 12), é feita sobre duas notas (Mi e Fá). A primeira parte, pela sua simplicidade e singeleza, corre o risco de ficar desinteressante nas mãos de um intérprete descuidado. Apesar da economia de elementos, é rica em mensagem, e o acompanhamento do piano "tempera" muito bem a melodia. Como sempre simples, mas com balanço, com ginga. Além das segundas, temos pouquíssimos saltos: saltos de $6^{\underline{a}}-$ no compasso 12 para 13 , quando passamos da primeira à segunda parte; saltos de 3 a - nos compassos 15 e de 17 a 20. Essa economia de variação melódica denota a importância de bem dizer o texto, pois o cantor não tem como fugir dele. Não há dificuldade técnica de extensão, emissão, ritmo, saltos etc. Mas a simplicidade e a transparência solicitadas pela peça exigem critério e bom gosto para que não deixemos deformar a pureza de intenção da obra.

O próprio tema já nos leva a essa conclusão, pois é uma prece a uma planta. Ora, é preciso um coração muito simples e puro para acreditar nisso e é exatamente assim que são até hoje as pessoas que inspiraram o compositor. Os "cabôcos" são capazes de acreditar piamente em coisas fantásticas e não acreditar em fatos científicos como a ida do homem à lua, por exemplo.

O compositor não nos dá indicação de andamento inicial, mas anota na partitura "com embalo"11, o que nos sugere um ritmo suave e sem arroubos, mais para o lento, dolente. Essa indicação nos reporta a um gesto musical narrativo inflexional, pois nos transporta a uma sensação induzida pelo jogo dos tempos fortes e fracos na acentuação do acompanhamento. Dá-se o mesmo com o tenuto do compasso 19. Outras indicações de expressão e andamento podem nos ajudar em nossa concepção musical: Calmo - compassos 5 e 21; Animando - compasso 9; Rallentando - compassos 11, 14, e 22; Exaltado - compasso 13; Tenuto - compasso 19; Avivando - compasso 17; Fermata - penúltimo e último compassos.

Podemos ver que a música começa em um plano, segue para um ápice e retorna para o mesmo plano. Torna-se mais viva quando o discurso é mais apaixonado e mais calma, quando retoma o tom de súplica (compassos de 5 a 8 e de 21 ao fim). Tudo muito de acordo com o texto. Ao "exaltado", "animando" e "avivando" segue-se sempre um rallentando, o que denota alteração de emoção, ora ansioso, ora abandonado à própria sorte.

Apesar de não haver indicação de dinâmica inicial, temos outras indicações durante a peça que nos dão a idéia de qual será a mais apropriada para o início: Crescendo (sinal) - compassos 6 para 7, 10, 14 e 17; Decrescendo (sinal) compassos 8, 11, 15, 18 e 22; Forte - compasso 25; Diminuendo - compassos 18 e 23; Piano - último compasso.

Existem alguns cromatismos no decorrer da obra. Nos compassos 10, 14,16 e 18, aparece um pequeno grupo cromático de três notas de caráter ornamental e expressivo que, ao mesmo tempo em que "enfeitam" a música, contribuem para amenizar o salto de $5 \mathrm{a}$, dando fluidez à melodia. 


\section{Tamba-tajá \\ Canção Amazônica}

(1934)

Lenda Amazônica $N^{\circ} 3$

Waldemar Henrique (1905-1995)
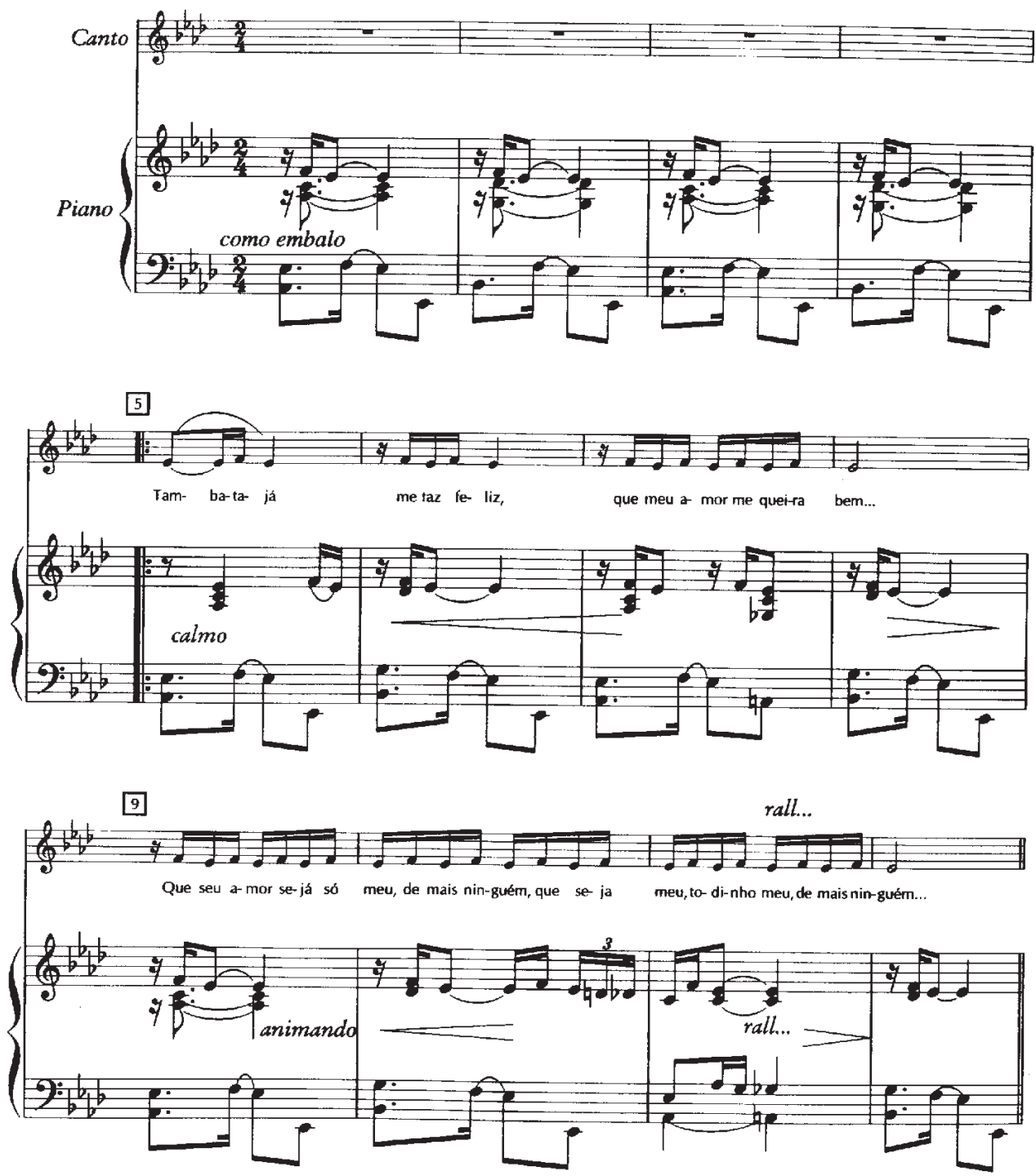

Composto graficamente em novembro de 1995, pela Fundação Carlos Gomes (Belérn - Pará - Brasil)

A canção tem duas seções que se repetem duas vezes e está dividida em:

- Introdução: compasso 1 ao 4;

- Seção A: compasso 5 ao 12;

- Seção B: compasso 13 ao 20;

- Coda: compasso 21 ao 25. 
13

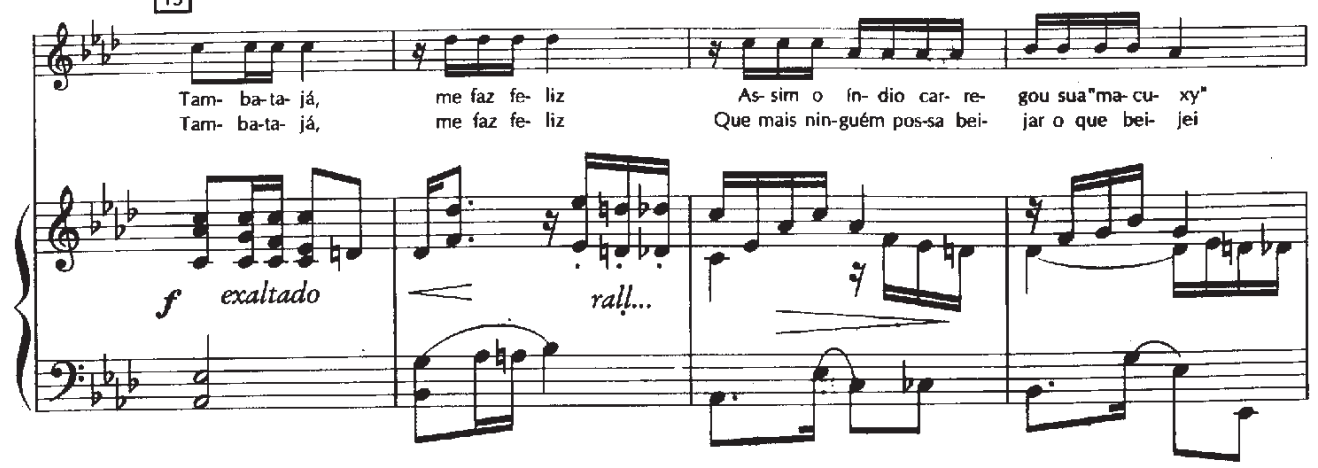

17

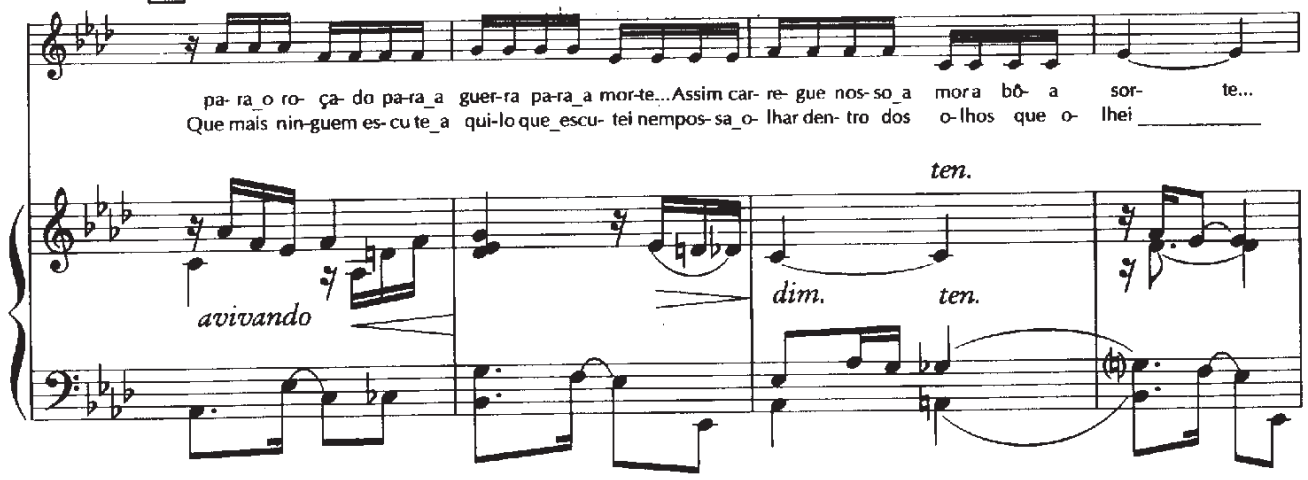

21

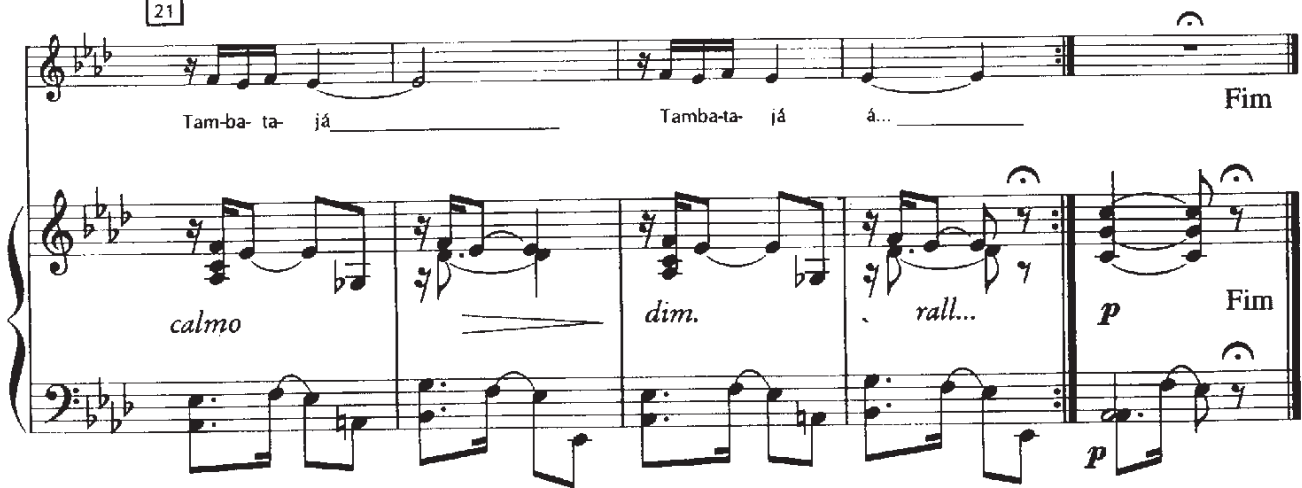

Partituras da canção Tamba-tajá.

Os elementos estruturais reforçam aspectos do texto. É visível a divisão do texto acompanhando a divisão da peça em seções. O acompanhamento é suave na primeira seção, quando a linha do canto é quase falada e o texto apresenta um pedido ainda contido. Já na segunda parte, quando o texto fica mais dramático, a estrutura é mais densa, sem, no entanto, ofender o caráter delicado da peça.

A harmonia é repetitiva, mas os acordes usados não são triviais. O comportamento harmônico da obra tem ligação com o conteúdo semântico do texto, 
pois nos reporta o tempo todo ao ambiente da mensagem poética. A figuração rítmica preponderante na mão esquerda do piano só muda nos compassos 11 , 13, 14 e 19, o que mantém o "balanço" da peça quase que constantemente. Essa figuração não tem clara ligação com ritmos característicos da região, mas tem um perfil que se enquadra na realidade regional pela sensação de movimento sugerida. Na melodia, temos como figuração preponderante quatro semicolcheias seguidas, o que nos sugere fluidez ao falar, naturalidade.

\section{Matintaperera}

\section{A Lenda da Matintaperera}

A Matintaperera ou Matinta ${ }^{12}$ é a velha feiticeira má da Amazônia. Assombra crianças e adultos. Segundo alguns, transforma-se no pássaro rasga-morta1 ha ${ }^{13} \mathrm{e}$, quando canta sobre a casa de alguém, prenuncia uma desgraça, geralmente de morte na família. Quando está na forma humana, apresenta-se como uma velha maltrapilha e, por vezes, traz uma rasga-mortalha no ombro. A velha Matinta caminha pelas ruas depois do cair da tarde, para pedir fumo ou comida aos transeuntes ou aos moradores das casas da vila ou cidade. É feia, usa os cabelos desgrenhados jogados sobre o rosto, veste-se com farrapos e, à noite, amarra uma lamparina na cabeça, o que lhe confere uma aparência sobrenatural. Sendo capaz de voar, corta os ares para ir em busca dos que lhe negam um pedido. Quando os encontra, assombra-os, amaldiçoa-os e os faz adoecer ou sumir. Não pode abraçar uma criança, pois a mesma desaparecerá para sempre sob seus andrajos. Quando a Matintaperera sente que vai morrer, pergunta a todo mundo "Quem quer? Quem quer?" E se alguma mulher afoita disser "eu quero" pensando se tratar de um presente receberá, na verdade, a sina de transformar-se em Matintaperera.

\section{Texto da canção - Versos de Antônio Tavernard ${ }^{14}$}

1. Matintaperêra/2. Chegou na clareira/3. E logo silvou.../4. No fundo do quarto/5. Manduca Torquato/6. De mêdo gelou./ 7. Matinta quer fumo,/ 8. Quer fumo migado,/9. Melôso, melado,/ 10. Que dê muito sumo./ 11. Torquato não pita,/ 12. Não masca, nem cheira,/ 13. Matintaperêra/ 14. Vai têla bonita./ 15. Matintaperêra de tardinha vem buscar/ 16. O tabaco que hontem à noite eu prometi./ 17. Queira Deus ela não venha me agoirar...(bis)/ 18. Ah! Matinta, Preta velha, mãi maluca, Pé de pato,/ 19. Queira Deus ela não venha me agoirar.../ 20. Matintaperêra/ 21. Chegou na clareira/22. E logo silvou.../ 23. No fundo do quarto/24. Manduca Torquato/25. De mêdo gelou./ 26. Que noite infernal,/27. Soaram gemidos,/28. Resmungos, bulidos/29. Do gênio do mal/ 30. E até de manhã,/31. Bem perto da choça/ 32. A fúnebre troça/33. Dum vesgo acáuan!

\section{Análise do texto}

Essa lenda nada tem de sensual. É cercada apenas de medo e da sensação de impotência diante de uma força maléfica superior. 
O autor da poesia usou apenas uma palavra do vocabulário regional: Matintaperera (ou Matinta) - a velha feiticeira que é tema da canção. Temos também algumas palavras e expressões que não são regionais, mas colocamos aqui porque quase já não são usadas hoje. São elas:

- Silvou (verso 3): assobiou;

- "Fumo migado,/ Melôso, melado, que dê muito sumo" (versos 8, 9, e 10): tabaco cortado em pedacinhos que, quando mastigado, não seja seco e tenha sumo farto.

- “Não pita,/ Não masca, nem cheira" (versos 11 e 12): não fuma, não mastiga nem cheira o tabaco (hábitos comuns antigamente).

- "Vai tê-la bonita" (verso 14): vai levar a melhor.

- Agoirar (versos 17 e 19): agourar, desejar ou promover o mal.

- Choça (verso 31): choupana, palhoça.

- Troça (verso 32): zombar, rir-se de.

- Acáuan (verso 33): espécie de gavião predador de cobras, cuja presença, segundo uma crença indígena, prenuncia a chegada de um hóspede.

O autor não usou recurso algum para caracterizar o falar da região.

\section{Aspectos musicais}

A canção "Matintaperera" foi escrita em 1933, em Ré menor, e sua extensão vai do Dó \# central ao Ré uma oitava acima. Mais uma vez, a escrita confortável do compositor favorecerá a articulação do discurso.

Nessa canção, curiosamente, foi utilizado largamente o modo dórico na célula que se repete com freqüência em toda a peça (compassos 1, 2, 3, 4, 6, 14, $26,33,34$ e 35). É um gesto musical descritivo e mimético, pois imita o assobio da Matinta, marcando assim a presença funesta e indiscutível da entidade. Como gesto musical, também se encontra integrado à representação teatral, uma vez que ajuda a caracterização da personagem Matintaperera.

O acompanhamento é altamente inflexional e confere ao discurso musical uma extrema proximidade com o discurso falado, uma característica que já notamos antes em todas as canções aqui analisadas. Isso nos ajudará a imprimir veracidade à nossa atuação, bastando para isso tirarmos partido da naturalidade.

Temos nessa canção um uso maior de intervalos de quarta, quinta e sexta (compassos 8,11 para 12, 12, 12 para 13, 20, 28 e 32). Mesmo assim, não constituem dificuldade alguma de execução.

Novamente o compositor marcou a fatalidade do drama com muitas linhas melódicas descendentes, que aparecem no canto e, mais ainda, no acompanhamento, com cromatismos expressivos nos compassos 7, 13, 15 e 23, que aumentam o caráter de funesto da peça. Mais uma observação que podemos utilizar a nosso favor na concepção interpretativa.

A divisão da peça é a seguinte:

- Introdução: do compasso 1 à metade do compasso 4 ouvimos repetidas 
vezes o assobio que anuncia a chegada da Matinta. Já deveremos posicionar nosso olhar e nosso corpo de maneira a deixar transparecer o medo e a angústia de quem sabe que vai se encontrar com esse gênio do mal.

- Seção A: da metade do compasso 4 à fermata do compasso 12. O cantor narra o drama que se desenrolará a seguir. Vale a pena lembrar que, quando se conta uma história de "cabôcos", deve-se dar vida aos fatos narrados para envolver o ouvinte na atmosfera da história.

- Seção B: da anacruse do compasso 13 à fermata do compasso 24. Aí temos uma importante mudança de foco narrativo. Quem fala nesse momento é Torquato, a vítima da Matinta, que num primeiro momento está conversando com a entidade, depois, a sós, manifesta o seu medo da velha, depois a amaldiçoa num lampejo de revolta, para logo depois ceder ao medo outra vez. Podemos tirar partido cênico dessa observação. O próprio compositor nos diz ser "lamentoso" o começo do discurso evoluindo para um rallentando (submissão). Depois, segue num "animando" e crescendo (medo), que caem num "brusco" (amaldiçoando), com novas alterações de expressão e andamento (volta ao medo). As informações do compositor são precisas e altamente coerentes com o texto.

- Repetição da Seção A: da anacruse do compasso 25 até a metade do compasso 33 a música retorna com versos diferentes (a partir do compasso 28), mas tem finalização diferente da primeira parte (compasso 32), pois desta vez o tema conclui-se e volta à tônica (compasso 33). A história termina assim, de modo trágico, evocando um clima místico de fatalidade e assombramento. Material excelente para a interpretação, que poderá atingir muito facilmente o público, se conseguirmos imprimir a ele a veracidade necessária.

- Codetta: do compasso 33 ao 36, o compositor retoma os assobios da Matinta feitos pelo piano e seguidos pelo canto, para marcar a vitória da velha feiticeira sobre o pobre Manduca Torquato, como para nos dizer da fatalidade do acontecido. Não devemos perder de vista a importância da manutenção desse clima até o último som do piano, diminuindo o volume do seu discurso sonoro, mas sem perder minimamente a expressividade do corpo e da face.

Na parte harmônica, o compositor utilizou uma gama maior de acordes em relação às canções anteriores e, embora ainda mantenha o acorde de tônica em compassos seguidos, utiliza-o menos intensamente. Isso se deve às alterações de foco narrativo e emocional do texto, que pedem diferenciações e servem para corroborar a mensagem falada. Podemos observar também a preponderância da figura rítmica das tercinas seguidas na linha do canto, que é estritamente silábico. Isso nos remete à fluência de emissão do texto e à acentuação poética, que devemos observar sempre.

\section{Uirapuru}

\section{A lenda do Uirapuru}

Havia, no Sul do Brasil, uma tribo de índios cujo cacique era amado por duas jovens muito bonitas. Não sabendo qual delas escolher para esposa, o jo- 
vem cacique prometeu que se casaria com aquela que tivesse melhor pontaria. Assim sendo, fez-se uma competição e as duas jovens atiraram suas flechas, mas só uma delas acertou o alvo e casou-se com o cacique. A jovem que perdeu a prova se chamava Oribicy. Ela chorou tanto por ter perdido seu amado, que suas lágrimas formaram um córrego. Sua tristeza era tanta, que pediu a Tupã que a transformasse num passarinho para que ela pudesse visitar seu amado sem ser reconhecida. Tupã realizou o desejo da moça e Oribicy, com sua nova forma, voou até o amado. Para sua grande tristeza, constatou na visita que o cacique vivia muito feliz com sua jovem esposa. Oribicy resolveu ir embora e voou para o Norte. Tupã, para consolá-la, deu-lhe um canto especial, que a faria esquecer sua dor enquanto o entoasse e atrairia quem quer que o escutasse. Assim, a jovem não ficaria solitária.

É por isso que o uirapuru, o pássaro que não é pássaro, vive a cantar e a atrair com seu canto todos os que o ouvem. Esse fenômeno acontece realmente. $\mathrm{Na}$ floresta, mesmo se todos os pássaros estão a cantar enchendo o ar de melodias e gritos diversos, quando o pequeno e cinzento uirapuru inicia seu canto, todos os outros silenciam e, o que é ainda mais interessante, vêm depositar aos seus pés oferendas: sementes, galhos, alimento.

\section{Texto da canção - Versos de Waldemar Henrique ${ }^{15}$}

1. Certa vez de "montaria"/2. Eu descia um "paraná"/3. O caboclo que remava/4. Não parava de falá(r)/ 5. Á, á... Não parava de falá(r)/ 6. Á, á... Que cabôclo falador!/ 7. Me contou do "lobisomi"/ 8. Da mãi-d'água, do tajá,/9. Disse do jurutahy/ 10. Que se ri pro luar/11. Á, á... Que se ri pro luar/ 12. Á, á... Que cabôclo falador !/ 13. Que mangava de visagem/14. Que matou surucucú/ 15. E jurou com pavulagem/ 16. Que pegou uirapurú/ 17. Á, á... Que pegou uirapurú/ 18. Á, á... Que cabôclo tentador!/ 19. Cabôclinho meu amor,/ 20. Arranja um pra mim/21. Ando "rôxa" prá pegar/22. "Um zinho" assim;/ 23. O diabo foi-se embora/ 24. Não quiz me dar/ 25. Vou juntar meu dinheirinho/ 26. Prá poder comprar./27. Mas, no dia que eu comprar/28. O caboclo vai sofrer/ 29. Eu vou desassocêgar/30. O seu bem-querer/31. Á, á... O seu bem-querer/32. Á, á... Ora deixa ele prá lá...

\section{Análise do texto}

Nesse texto, feito especialmente para a música, aparecem muitas palavras de uso regional e algumas que estão fora do vocabulário usual de hoje:

- "Montaria" (verso 1): canoa ligeira feita de um só bloco de madeira.

- "Paraná" (verso 2): braço de rio.

- "Lobisomi" (verso 7): lobisomem.

- Mãi-d'água (verso 8): figura lendária de bela mulher que mora no fundo do rio e encanta aqueles que a vêem ou ouvem sua voz, levando-os para as águas profundas de onde não retornam nunca mais ${ }^{16}$.

- Tajá (verso 8): planta de grandes folhas verdes, sem flor, de muita variedade na Amazônia e à qual se atribuem poderes mágicos. 
- Jurutahy (verso 9): pássaro que possui um canto triste.

- Visagem (verso 13): fantasma, aparição.

- Surucucu (verso 14): cobra de grandes proporções e das mais venenosas da Amazônia.

- Pavulagem (verso 15): gabolice, fanfarronada.

- Uirapuru (verso 16): passarinho de canto especial, o artista da floresta.

- "Rôxa" (verso 21): roxa de vontade, com muita vontade.

- “Um zinho" (verso 22): só um, apenas um.

Como características do falar regional, temos: a sugestão da supressão do$r$ final da palavra falar (versos 4 e 5), que está entre parênteses, para imitar o falar "cabôco".

Já dissemos antes, na análise musical, que o foco narrativo se desloca nos versos 19 e 23 e que podemos nos valer disso para incrementar nossa performance, mas gostaríamos de fazer mais uma observação sobre isso: o narrador é uma mulher, como vemos no verso 21 (“ando rôxa prá pegar...”). Isso é muito importante quando selecionamos repertório, pois, uma canção com texto escrito no feminino, nem sempre fica bem se for cantada por um homem, e vice-versa.

\section{Aspectos musicais}

A canção Uirapuru foi escrita em 1934 e dura aproximadamente 1'50". Tem tessitura de uma oitava a partir do Ré central e, como já nos parece de praxe do compositor, não oferece dificuldades técnicas para o executante.

Embora seja uma canção alegre, foi escrita em tonalidade menor (Ré menor), não se alterando durante toda a peça. É até interessante notar que o compositor não escreve nota alguma fora da escala escolhida para a peça, embora tenha feito uma modulação temporária nos compassos 17, 18 e 19. Na linha do piano não há cromatismos, nem acidentes ocorrentes. No solo do canto, aparece apenas um acidente no último tempo do compasso 17, que não marca especialmente a melodia.

Observamos a preocupação do compositor com a boa emissão do cantor, pois pede um "quasi falado" logo no primeiro compasso do solo do canto. Devemos nos esmerar para não deformar as palavras com uma impostação exagerada. A voz deve ser bem colocada, mas sem parecer artificial, pois a presença constante das semicolcheias na parte do canto nos mostra que o texto tem primazia sobre a melodia.

Apesar de ser extremamente silábica, a canção traz um tímido, mas expressivo vocalise sobre duas notas nos compassos: 10 para 11, 12 para 13, 28 para 29 e 30 para 31. Ele repete-se oito vezes na canção e dá-nos oportunidade de mostrar diferentes timbres e/ou entonações para um mesmo trecho, de maneira que as repetições não se tornem monótonas para o público.

A estrutura da obra mantém um contato estrito com a estrutura do texto, de maneira que, quando o foco narrativo se altera (segunda parte - compasso 
16), a melodia se modifica. Para observar melhor essa alteração, vejamos como a canção está dividida:

- Introdução: os cinco primeiros compassos, que trazem a notação "saltitante" e a dinâmica "crescendo" (sinal) e têm ao final do compasso 5 um acorde "tenuto", preparam o ambiente para a narração dos feitos do "cabôco". A introdução, como já dissemos, nos serve para preparar nossa postura e expressão corporal e facial.

- Seção A: do compasso 6 ao primeiro tempo do compasso 16, com três repetições. As repetições servem para o compositor apresentar a história e toda a narração dos feitos do "cabôco" falador e gabola. Temos três textos diferentes para a mesma melodia. É muito importante usarmos recursos cênicos e vocais para "colorir" essa passagem. As repetições apresentam, sutilmente escondida, uma mudança no grau de interesse do narrador, que é mulher, pelas façanhas do "cabôco". Devemos ler nas entrelinhas do texto para entender essa sutileza e dela tirar partido. Podemos ainda aproveitar expressivamente os rallentando do compasso 13 para imprimir nova intenção à frase que se repete.

- Seção B: do segundo tempo do compasso 16 ao fim. O foco narrativo desvia-se duas vezes. A primeira, quando o narrador que antes falava para o público ou para si mesmo, passa a dirigir-se diretamente ao "cabôco" para pedir-lhe um uirapuru (segundo tempo do compasso 16 ao primeiro tempo do 19); a segunda, quando o cabôco vai-se embora sem atender ao pedido e o narrador volta-se novamente para o público ou para si mesmo (segundo tempo do compasso 19 até o fim). Podemos usar muitos recursos como o direcionamento corporal, a mudança de entonação, de timbre, para enriquecer nossa performance.

Os silêncios dessa canção são muito eloqüentes. Após as fermatas dos compassos $6,14,15,16$ e 31, atuam como preparadores da continuação do discurso. Nos compassos 16 e 31, o silêncio também é transformador, enquanto nos demais (compassos 6, 14 e 15) serve de ponte entre as partes. Nos compassos 10 , 12, 28 e 30 e, discretamente, nos compassos 22 (após o tenuto) e 24 (após o rallentando) podem reunir transformação e separação ou ponte. Todos podem ser usados na sua função construtiva se utilizados estruturalmente, acrescentando muito mais significado ao texto poético e musical. Cabe-nos estudá-los, analisálos e explorá-los.

A parte harmônica é muito simples e poucos acordes se repetem alternadamente. Logo, o cantor é o foco central das atenções do público e isso nos dá ampla autonomia para conduzir nossa interpretação.

A linha melódica é toda construída com intervalos de $2^{\underline{a}}, 3^{\mathfrak{a}}$, e $4^{\mathfrak{a}}$, em que apenas um intervalo diferente ( $\left.7^{\underline{a}}\right)$ aparece no compasso 16 , marcando a segunda parte. Muitas linhas melódicas ascendentes emprestam à música uma feição alegre e brejeira e que tem grande apelo público. Com essa feição alegre e saltitante, torna-se fácil escolher um andamento, pois o compositor não o sugeriu na 
partitura. Também não há registro de dinâmica feito pelo autor, além dos sinais de "crescendo" e "decrescendo" nos compassos 2, 3, 21 e 22.

Embora não haja indicação de que se trata de uma dança, existe uma relação entre a figuração rítmica preponderante do acompanhamento do piano (a partir do compasso 7) e o ritmo regional do xote bragantino ${ }^{17}$. $\mathrm{O}$ acorde da mão direita do piano, na segunda metade do segundo tempo do compasso, marca um dos acentos da célula. Assim, vemos mais uma vez a necessidade daquela "ginga" que caracteriza a regionalidade da peça.

\section{Curupira}

\section{A lenda do Curupira}

O Curupira é o grande defensor da floresta. É um ser de forma humana, pequeno, esverdeado, com os cabelos cor de laranja, que tem os pés virados para trás e vaga pela mata zelando pelas árvores e animais. Volta-se contra qualquer um que queira caçar apenas por prazer, ou desmatar a floresta sem propósito. Por outro lado, é amigo dos que vivem na mata sem agredi-la, caçando apenas para alimentar-se e respeitando a flora. Para atrapalhar os que não agem com boas intenções ecológicas, o curupira tem muitas artimanhas. Pode assombrá-los com seus gritos agudos, açoitá-los, tornar-se invisível e aparecer em vários lugares, até fazer com que aqueles que tentam contra a vida na floresta percam o rumo. Também faz com que o bicho encurralado pelo caçador, vire meuã, que significa portar-se de repente como gente, fazendo gestos para implorar piedade. Assim, o caçador fica assombrado, não consegue mais fazer pontaria e foge apavorado. Diz-se que muitos caçadores, depois de terem visto a caça virar meuã, nunca mais se atreveram a caçar.

\section{Texto da canção - Versos de Waldemar Henrique ${ }^{18}$}

1. Já andei três dias e três noites/2. Pelo mato sem parar/3. E no meu caminho não encontrei/ 4 . Nem uma caça prá matar./ 5. Só escuto pela frente, pelo lado/ 6. O Curupíra me chamar,/7. Ora aquí, ora alí se escondendo/ 8. Sem parar num só lugar.../9. Por êsse danádo muitas vezes/ 10. Me perdí na caminhada/ 11. E nem Padre-Nosso me livrou/ 12. Desse malvado da estrada./ 13. Curupíra feiticeiro!/ 14. Sai de traz do castanheiro,/ 15. Pula prá frente,/ 16. Defronta com a gente,/ 17. Negrinho, covarde, matreiro./ 18. Deixa o cabôclo passar!

\section{Análise do texto}

O texto foi escrito especialmente pelo compositor para a canção. Tem como tema a lenda do curupira, que não é exclusiva da região Norte, possuindo características diferentes em cada região. Narra as dificuldades de um caçador que teve a má sorte de encontrar o curupira no seu caminho. Este ser mitológico não pode ser atingido por armas, nem pela prece mais poderosa do cabôco, o PadreNosso. Sendo assim, só restou ao caçador o pedido do verso 18 - "Deixa o cabôclo passar". O uso dos versos junto à melodia é totalmente silábico e o texto 
possui uma mudança de foco narrativo no verso 13. Aqui, o narrador deixa de falar das suas dificuldades para si mesmo, como num desabafo, e passa a dirigirse diretamente à entidade mágica que o persegue. Não temos palavras de uso regional

\section{Aspectos musicais}

A canção "Curupira” é de 1936. Das canções analisadas aqui, é a de maior extensão vocal, indo do Si central, ao Mi uma oitava acima. É também a mais curta, pois dura aproximadamente l'.

Foi escrita em Mi b Maior, mas tem sua introdução na tonalidade de Fá m. Tem texto do próprio Waldemar Henrique e traz o andamento marcado com precisão: Moderato semínima $=84$. Não há nenhuma anotação de dinâmica até o 60 compasso, o que dá certa liberdade de escolha ao executante. Apresenta muitos cromatismos. Temos um cromatismo ornamental no compasso 16 (mão direita do piano) e um cromatismo estrutural muito interessante no baixo do piano que surge logo na introdução. São quatro notas em escala descendente que aparecem seis vezes em toda a canção (compassos 1, 3, 5, 7, 9, 11 e 13), acompanhando o primeiro foco narrativo do texto e a primeira parte da peça.

A canção foi escrita na forma binária simples e está dividida em:

- Introdução: compassos 1 e 2. As escalas ascendentes e descendentes da mão direita do piano imprimem um gosto de corrida, que culmina com acordes saltados e precedidos de apoggiaturas. Podemos ter aqui um gesto musical mimético e descritivo da corrida e dos saltos do curupira, que "ora aqui, ora ali” é ouvido pelo caçador. Já nessa introdução deveremos imprimir ao rosto e ao corpo a atitude de quem está em meio à agitação sugerida pela música.

- Seção A: do compasso 2 a 14. Devemos dar atenção ao fato de que o caçador - que é quem narra a história - após três dias de caçada infrutífera, já deverá estar cansado da presença do curupira. Talvez já esteja irritado, talvez com fome, ou preocupado por não ter o que levar de alimento para quem ficou em casa. Essa compreensão do texto e da agitação da música servirá de base para a construção da nossa postura e gestualidade corporal e facial. Há muito texto para ser dito em muitas notas seguidas durante toda a canção. Devemos dar muita atenção à dicção e ao andamento, que se for maior que o pedido pelo autor, pode prejudicar a compreensão das palavras.

- Seção B: do compasso 15 ao 20. Aqui, temos uma mudança de foco narrativo do texto, que também é sabiamente acompanhada por uma mudança no acompanhamento. Esse fato nos oferece uma oportunidade para mudança de postura em geral. O caçador se dirige, a partir desse momento, diretamente ao curupira e sabe onde ele está - "sai de traz do castanheiro". Desafia-o e o achincalha com uma notação de "apressando" (compasso 17), que pode nos ajudar a imprimir ainda mais veemência e expressão ao discurso. No final desta parte - após uma fermata que traz um silêncio 
preparador do discurso que está por vir e, ao mesmo tempo, transforma o tom desse discurso - antes agressivo - em um pedido, uma queixa. Esse pedido final, rallentando, faz um contraste com o apressando anterior e oferece uma excelente oportunidade para que se mostre versatilidade de timbre e performance.

Enquanto a última nota está sendo cantada, o piano encerra a peça com outra série de acordes precedidos de apoggiaturas, sob os quais o compositor anotou um original "fugindo", que só pudemos interpretar como a fuga do curupira. Logo, o compositor estava imbuído da intenção de escrever descritivamente e integrado à narrativa dos fatos.

Mais uma vez, observamos que a estrutura do texto e da música caminham lado a lado. As escalas agitadas que marcaram a primeira parte da canção - quando o texto apresenta o problema sem solução do caçador - dão lugar às notas mais tranqüilas do ritardando (compassos 15 e 16), que aparece no momento em que o homem pára e enfrenta seu adversário. Uma aceleração progressiva, aliada a um ritmo mais pausado na pronúncia do canto nos compassos 17 e 18, dá mais veracidade ao discurso irritado e cansado da vítima do curupira. No final (compassos 19 e 20), o andamento cede completamente na linha do canto, que nos remete ao discurso cansado do caçador. No piano, o cedendo se desfaz somente no último compasso onde, como já dissemos anteriormente, o curupira "foge", ou se afasta, deixando o "cabôco" passar.

Nessa canção, talvez porque seja posterior a todas as outras, temos muito mais intervalos de $4^{\underline{a}}, 5^{\underline{a}}$ e $6^{\underline{a}}$ na melodia. Apesar disso, ainda temos o predomínio de intervalos menores e não vemos maiores dificuldades técnicas que possam prejudicar um intérprete, ainda que iniciante. $\mathrm{O}$ "bem dizer" o texto, com veracidade e espontaneidade, continuam sendo os desafios desta peça.

\section{Manha-Nungára}

"Manha-Nungára" significa "mãe de criação". Foi escrita em homenagem à mãe de criação de Waldemar Henrique, Estefânia Rosa da Costa ${ }^{19}$. Não sendo uma lenda, está incluída na classificação das canções de Waldemar Henrique como Lenda Amazônica por abordar a lenda do boto sob novo enfoque. Nesta canção, o autor nos fala de uma figura muito comum na região Norte: a mãe adotiva, ou mãe de criação. Os processos de adoção ou delegação de custódia não passam, muitas vezes, pelos trâmites legais. O "cabôco" não pensa como as pessoas da cidade e se lhe apraz, por qualquer motivo, dar um filho seu para um parente, ou criar o filho de alguém próximo, faz isso sem maldade e sem burocracia.

\section{Texto da Canção - Versos de Waldemar Henrique ${ }^{20}$}

1. Do alto palmar d'uma jussára,/2. Vem o triste piar da iumára./ 3. Os tajás pelo terreiro estão chorando/4. E no rio, resfolegando/ 5. Bôto branco boiou!...Ô...ồ.../ 6. Sentada na rêde, cunhã está rezando/ 7. A réza que ManhaNungára ensinou.../ 8.'- Tupan, quem foi que me enfeitiçou?/ 9. - Manha- 
Nungára!/ 10. O grito rolou pela caiçara,/ 11. Mãi-velha se espantou./ 12. Embaixo, na treva do rio,/ 13. Dois corpos em cio,/ 14. Lutando enxergou./ 15. E pelo barranco/ 16. De novo soou/17. O grito de angústia/ 18. Que a cria soltou:/ 19. - Manha-Nungára!

\section{Análise do texto}

O texto dessa canção traz novamente a lenda do boto como tema. Dessa vez, temos uma descrição mais detalhada do cenário e da vítima, que pede socorro. Tem desvios de foco narrativo nos versos 9,10 e 20 , quando é a cunhã quem fala. No restante, é o narrador quem descreve a cena

No cenário descrito, tão verdadeiramente amazônico, temos algumas palavras de uso regional:

- Jussára (verso 1): palmeira do açaí.

- Iumára (verso 2): passarinho de canto muito triste.

- Cunhã (verso 6): o mesmo que cunhantã: moça.

- Caiçara (verso 10): cerca de pau-a-pique em redor de uma roça.

\section{Aspectos musicais}

A canção "Manha-Nungára", de 1935, tem letra do próprio Waldemar Henrique. Apresenta uma politonalidade na qual a tonalidade básica de Sol M convive simultaneamente durante a peça com sua tonalidade relativa Si Menor. Divisão:

- Introdução: compasso 1. Curtíssima, essa introdução termina em uma fermata, que é um gesto musical preparatório para a narrativa do canto. $\mathrm{O}$ piano apresenta o motivo principal do acompanhamento, que se repetirá várias vezes por toda a canção. Lembramos mais uma vez que a introdução já é a música e que já devemos estar com postura expressiva totalmente pronta para oferecer mais elementos para o público entrar no ambiente da canção.

- Seção A: do compasso 2 à metade do último tempo do compasso 11. Aqui, o narrador descreve uma paisagem triste, que nos deixa à espera do que está por vir. Embora tenhamos chamado esta parte de seção A, ela nos parece auditivamente uma segunda grande introdução. Não traz um tema que guardemos na memória e, embora termine na tônica, não sentimos que a melodia descansa aí, pois a repetição da dominante Ré na mão esquerda do piano pede novamente a presença da tônica para se resolver.

O compositor cria, assim, uma atmosfera de tensão, ainda que muito leve. Mais de expectativa do que de dramaticidade. Devemos manter essa leve atmosfera de suspense, traduzindo-a em expressão corporal, trabalhando com gestos, olhares e expressão facial. A parte que vem a seguir ainda se encontra na mesma atmosfera.

- Seção B: da metade do último tempo do compasso 11 à metade do compasso 18. Novamente temos a sensação de que a música não concluiu sua idéia. O texto termina em uma pergunta que fica sem resposta. A melodia, 
ainda mais. Um acorde de $6^{\underline{a}}$ invertida é o responsável por essa sensação de não conclusão. Podemos tirar partido dos recursos timbrísticos para o "falado quasi" (metade do último tempo do compasso 16, até a metade do compasso 18). Uma notação de "brusco" no piano antecede a pergunta angustiada da cunhã, que culminará com um grito, um pedido de socorro. Deve ser feito com muita veracidade e expressão, podendo ser até realmente falado, sem risco de parecer fora de estilo.

- Coda: metade do compasso 18 à metade do último tempo do compasso 19. Eis o clímax e a resolução das duas seções anteriores. Toda a carga dramática contida no texto e na música culmina com esse final. É o repouso harmônico, poético e expressivo da canção. Assim deve ser também na nossa atuação. Toda a atmosfera de suspense criada na peça se diluirá nesse apelo desesperado. É também o clímax da dinâmica, que crescerá rapidamente e se diluirá em seguida, como uma onda.

- Seção C: da metade do último tempo do compasso 19 à metade do terceiro tempo do compasso 25 (para o canto) ou metade exata do compasso 25 (para o piano). Retomamos a descrição, a não conclusão harmônica e o clima de expectativa, que inicia com um precipitando (compasso 20), que aumenta o grau de dramaticidade do discurso lítero-musical. A partir daí, tudo caminhará para o allargando com crescendo dos compassos 24 e 25, em uma frase ascendente que culmina em mais um grito de angústia na metade do compasso 25 e 26, a segunda Coda da canção.

O processo de composição politonal empresta à canção muitos momentos alternados de tensão e relaxamento. A dinâmica deve ser dosada com sabedoria para que o clímax da peça (primeiro tempo do compasso 26) receba todo o seu potencial vocal e expressivo. O morrendo que vem em seguida traz consigo a fatalidade, a confirmação de que a cunhã não conseguiu fugir à sedução do boto. Seu apelo foi em vão, pois Manha-Nungára não conseguiu salvá-la. É muito significado para pouca música. Buscaremos usar todos os recursos cênicos e musicais ao nosso alcance para dar a esse final tão curto o peso da resolução de todas as tensões da peça. Atenção: que não se entenda fazer coisas demais. Queremos dizer que é preciso escolher o gesto, a dinâmica e as formas de expressão mais adequadas, para traduzir a mensagem do texto poético e musical. O intérprete precisa pesquisar, procurar no seu universo vocal, gestual, facial e de postura, a melhor maneira de expressar o conteúdo semântico do texto cantado. Não há repetição de texto nem música, excetuando a coda, que aparece duas vezes, sempre com caráter conclusivo.

Cada seção da canção está separada da anterior por silêncios que desempenham função secionadora e, ao mesmo tempo, transformadora de uma seção para a outra; ou mudam as imagens descritas ou mudam as emoções do narrador.

A estrutura da obra acompanha fielmente a estrutura dos versos, reforçando com a harmonia todas as nuances do texto poético. A melodia foi construída com predominância de graus conjuntos. Poucos intervalos de $4^{\underline{a}}$ aparecem nos 
compassos 5,5 para $6,12,19,23$ e 26 , apenas um de $6^{\underline{a}}$ no compasso 18 e um de 7 a no compasso 9. Os intervalos maiores não servem para marcar especialmente nenhuma passagem. As linhas melódicas descendentes que marcam a canção do início ao fim emprestam dramaticidade à peça e descrevem a fatalidade e a angústia da cunhã, que não pode resistir à magia do boto. As figurações rítmicas da parte do canto estão colocadas de maneira a impulsionar o discurso de acordo com as alterações emocionais do texto, que coincidem com as variações de andamento descritas na partitura.

Com duração de aproximadamente 1'50", possui andamento fixado pelo compositor: Calmo: semínima $=72$ e tessitura que vai do Ré central ao Mi oitava acima. Não oferece dificuldades técnicas para o cantor, mas o desempenho artístico é fundamental, ou a canção será empobrecida na força da sua expressão. $\mathrm{O}$ texto é silábico, mas uma pequena vocalização nos compassos de 10 para 11 aparece com a função de descrever o movimento do boto na água, vindo à tona e submergindo novamente. Temos aí um claro gesto musical descritivo integrado à narrativa. É um momento único na peça. Merece destaque.

Essa canção apresenta uma característica inovadora, com relação às outras. Tem uma concepção contemporânea, com uma divisão que não obedece a padrões tradicionais. A linha melódica pouco variada fica muito próxima da fala, o que lhe confere um certo ar de recitativo. Como sabemos, o recitativo é o momento de movimento cênico na ópera. Opõe-se à ária que, por falar de sentimentos, é mais estática. Nessa canção, Waldemar faz uma nítida opção por movimento teatral, só que coloca isso em um gênero estático como é o da canção de câmera.

\section{Conclusão}

Conferindo os resultados de nossas análises, observamos que a música regional de Waldemar Henrique é resultado de uma concepção composicional que não tem por objetivo um produto final de aparência grandiosa. Sua maneira de retratar sua terra é simples e direta, embora sempre impregnada de poesia. Por esse motivo, ele é considerado tão fiel no seu registro. Apesar de retratar motivos regionais nas suas lendas amazônicas, Waldemar usou sempre temas próprios e, mesmo valendo-se de muitas figurações rítmicas regionais, utilizou-as sem exageros.

$\mathrm{Na}$ escrita musical do maestro há uma grande economia de elementos. $\mathrm{Na}$ linha melódica, ele utilizava poucos saltos e quase nenhuma vocalização. Optou por uma extensão confortável e central, de maneira que a melodia não interferisse no entendimento do texto com notas excessivamente altas. Nada em sua escrita oferece ao executante dificuldades de ordem técnica.

Sua escrita harmônica não se baseia em grande variação de acordes, mas percebe-se que ele utiliza com mestria os recursos harmônicos, escrevendo dessa maneira as canções amazônicas para manter o padrão de simplicidade que permeia sua visão da música regional. Mesmo seguindo esse padrão de simplicidade, consegue efeitos que fazem sua música parecer exótica, mas agradável aos ouvidos. 


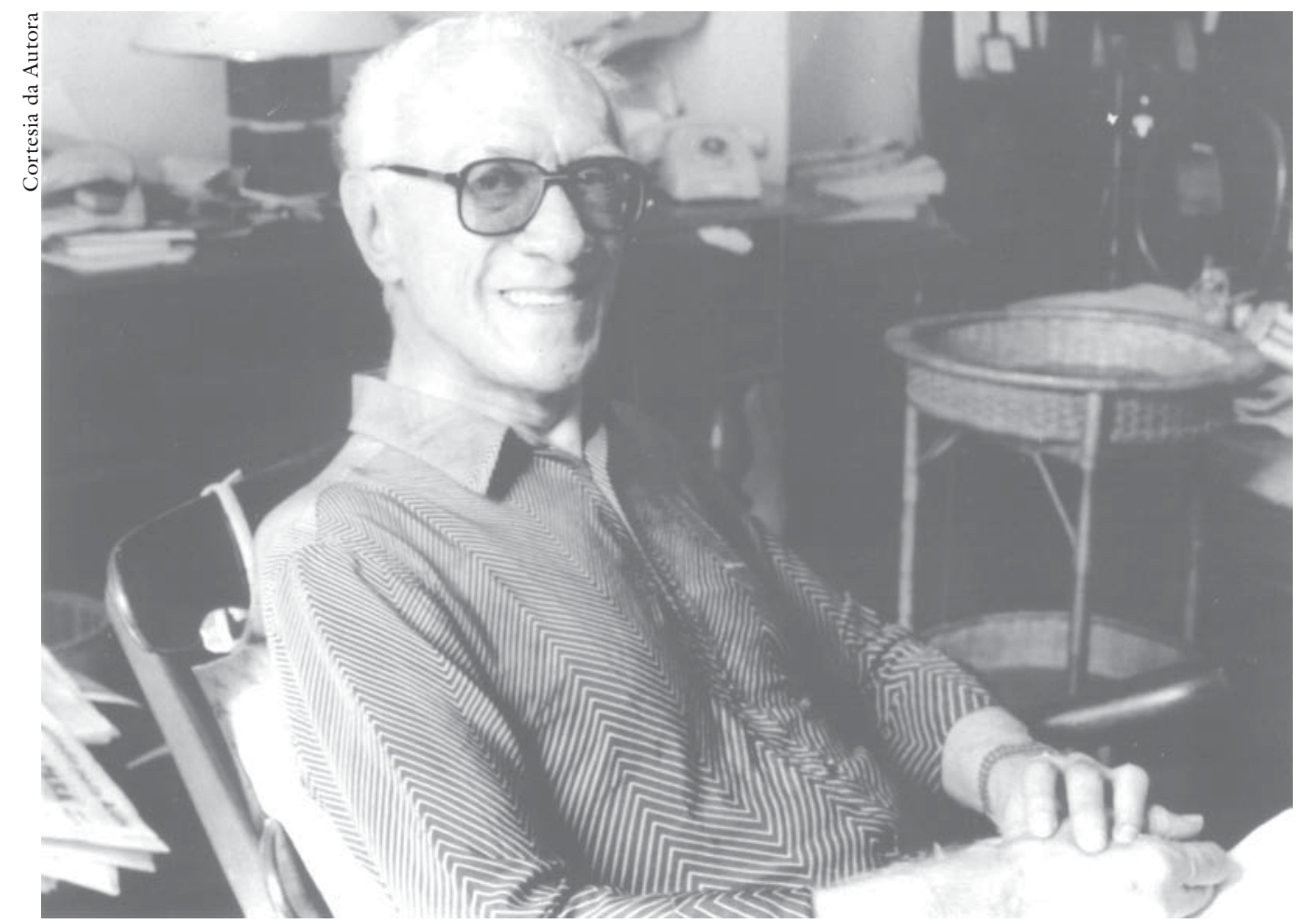

Em 2005 se comemora o centenário deWaldemar Henrique, nascido em 15 de fevereiro de 1905.

Por vezes, sua música mantém algumas "batidas" (padrões repetidos de células rítmicas) por longos períodos, mas isso foi feito com o intuito de conservar por mais tempo uma mesma atmosfera descritiva. Não vemos figurações complexas, ou de difícil execução, que exijam maior tempo para serem assimiladas.

Quanto à prosódia, Waldemar Henrique é exemplar. Não detectamos erro algum nesse aspecto. Para ele, o texto é soberano e determinante de todas as diretrizes da sua criação musical. É notável a maneira como todos os elementos da música estão a serviço do texto, não só no sentido da métrica, mas também na compreensão da mensagem e de seu contexto. Tudo o que é colocado na partitura é feito de maneira a auxiliar o ouvinte a compreender a palavra, a mensagem. Os textos são utilizados quase que totalmente de maneira silábica e os vocalizes, que aparecem raramente, são muito curtos, apenas extensões de sílaba. É do texto que o executante poderá tirar maior partido no incremento da sua performance, e isso exige boa dicção e uma emissão sem artificialismos que prejudiquem a compreensão da mensagem, como a impostação operística, por exemplo. Tudo isso denota grande cuidado com o entendimento da mensagem por parte do compositor.

Waldemar gosta de preparar a entrada do canto com introdução. Entretanto, nas Lendas Amazônicas elas são sempre curtas e não expõem o talento virtuosístico do pianista. Na sua abordagem dos temas regionais, as introduções são uma preparação rápida do público para a recepção da mensagem, feitas de maneira discreta para não roubar as atenções devidas ao solista, o narrador das histórias. 
O acompanhamento das peças está sempre apoiando o canto discretamente, nunca em primeiro plano. Dá a justa carga dramática exigida pelo conteúdo poético e acrescenta ou diminui a quantidade de notas dos acordes coerentemente. Mais agitação, mais veemência por parte do texto merecem mais notas na partitura, pois o cantor estará dando maior volume sonoro nesses momentos e viceversa. Assim, o compositor contribui para que o solista não seja suplantado pelo acompanhamento. É claro que, apesar dessas providências cuidadosas, o cantor pode contar com um pianista de toque mais pesado ou solista, que pode suplantálo em sonoridade. Entretanto, relativamente aos processos composicionais, o maestro tomou todas as providências para evitar essa possibilidade.

O ponto que nos parece mais interessante na nossa pesquisa é a constatação de que Waldemar Henrique tem uma visão teatral da performance do cantor. Ele utiliza sua música como recurso que reforça e auxilia o tempo todo essa performance, contribuindo para sua veracidade. Escreve sempre o acompanhamento de maneira altamente gestual e usa com muita freqüência silêncios construtivos para acrescentar mais significado à música. A música tem a função de dar inflexão, pontuação, entonação e maior expressividade ao texto que está sendo "narrado" pelo cantor. O compositor chega ao requinte de, por vezes, colocar na partitura do piano os efeitos que caberiam ao sonoplasta do teatro. Para cada novo foco narrativo são acrescidos novos elementos, no intuito de evidenciá-lo. Assim, ele cria texturas, ambientação, paisagens e intervenções sonoras.

Essa característica acentuada de movimento foi explorada intensamente na canção "Manha-Nungára!". Foi isso o que nos motivou a optar por deixá-la para nossa última análise. É o coroamento da concepção teatral de Waldemar Henrique. A mescla de características narrativas e dramáticas remonta ao estilo concitato, de Cláudio Monteverdi. Nele, os executantes devem dar igual importância à música, ao drama e à cena. Esse estilo transforma a música em drama com o propósito de mover o espírito (Igayara, 1999). Da mesma forma, Waldemar Henrique utiliza os elementos da música para obter o envolvimento do público com suas canções.

Não podemos saber se Waldemar Henrique tinha consciência de estar compondo segundo as premissas de Cláudio Monteverdi ou se exclusivamente tentava registrar a maneira especial com que o "cabôco" conta suas histórias. O contador de histórias do Norte é quase um artista de teatro. Utiliza olhares, gestos largos, alterações de timbre de voz e, é claro, alguns exageros, que ajudam a impressionar os ouvintes. Essa segunda hipótese nos parece mais lógica, pois, como temos a oportunidade de ouvir de perto essas estórias, contadas pelas pessoas nativas da região, identificamos na suave condução da interpretação que Waldemar registrou, na partitura, sua aproximação, consciente ou não, da narrativa "cabôca".

Nós, que já tivemos a oportunidade de vivenciar essa "teatralidade narrativa" no seio da família e em nossas andanças pelo interior da Amazônia, identificamos, em suas notações de expressividade na partitura e na sua condução musical 
como um todo, a tentativa de levar o intérprete a envolver-se ao máximo com o texto falado, mais que com a própria melodia. Sua escrita dá margem a uma boa movimentação cênica, facilitando o envolvimento do público com o intérprete. Isso é altamente intencional. Ele direciona o cantor, guia-o para uma interpretação mais espontânea.

Também já tivemos a oportunidade de cantar várias vezes essas canções para algumas comunidades ribeirinhas que ainda vivenciam essas lendas. São locais ainda dentro da realidade da floresta, onde as pessoas vêm assistir ao recital de barco e deixam seus chinelos à soleira da porta. Descalços e respeitosos como se estivessem em um templo, sentam para nos assistir sem se importar com os sapos e pássaros que fazem "fundo para a nossa música". Essa gente vibra com as lendas de uma maneira especial, impressionante. Ao final das apresentações, algumas pessoas vêm nos contar outras histórias e vemos outra vez o maravilhoso universo descrito por Waldemar se expor diante dos nossos olhos. A diferença é que não há música nessas narrativas. Essa contribuição nós devemos a Waldemar Henrique.

\section{Notas}

1 Foi mantida a ortografia da edição.

2 A UFPa tem um vasto trabalho de pesquisa e recolhimento dessas histórias (ver Simões, 1995 a, 1995b e 1995c).

3 Talvez por beneficiar o registro vocal da principal intérprete das obras de Waldemar Henrique, Idália da Costa Pereira, sua irmã, cujo nome artístico era Mara.

4 Ver introdução e primeiro capítulo em Aliverti, 2003.

5 Dança sensual de origem negra, da cidade de Cametá. Foi assim denominada em alusão à atividade de captura da grande quantidade de siris do lugar.

6 Fazendo parte de maneira indissociável do pensamento musical, ao nível da estrutura, dos procedimentos de composição e de instrumentação.

7 Do Tupi: Mboi-cobra + una - preta, ou Mboi - cobra + açu - grande. Também escrita como está no verso da canção: Boi-Úna, palavra composta.

8 Foi mantida a grafia original.

9 Planta sem flor, com folhas em forma de coração. Contam em grande variedade na Amazônia. É conhecida em outras regiões como tinhorão.

10 Foi mantida a ortografia da edição.

11 O embalo da Amazônia é o embalo de rede. É muito mais dentro da nossa realidade nortista uma rede para embalar, do que uma cadeira. As mães, por exemplo, até na capital preocupam-se em pôr uma rede no quarto das crianças, pois é muito mais fácil fazê-las adormecer.

12 Também conhecida como: Matinta Pereira, Mati-Taperê, Mat-Taperê, Matim-Taperê, Titinta-Pereira.

13 Espécie de coruja conhecida como: “coruja-das-torres”. 
14 Foi mantida a grafia da partitura.

15 Idem.

16 Também é figura mitológica da Amazônia, correspondente da "sereia" européia.

17 Dança regional que se fixou com maior força nos arredores da cidade de Bragança (PA).

18 Foi mantida a ortografia da edição.

19 Tendo perdido sua mãe verdadeira, Joana da Costa, com um ano de idade e tendo seu pai casado com a cunhada, sua tia Estefânia foi a mãe que Waldemar conheceu e amou devotadamente por toda a vida.

20 Foi mantida a grafia da partitura.

\section{Referências}

ALIVERTI, Márcia Jorge. Uma visão sobve a interpretação das canções amazônicas de Waldemar Henrique. Dissertação de Mestrado. São Paulo, Escola de Comunicações e Artes da Universidade de São Paulo, 2003.

ALVES FILHO, Armando, ALVES JÚNIOR, José e MAIA NETO, José. Pontos de história da Amazônia, vol. I. $3^{\text {a }}$ ed. rev. ampl., Belém, Paka-Tatu, 2001.

BEZERRA, Ararê Marrocos e PAULA, Ana Maria T. de. Lendas e mitos da Amazônia Rio de Janeiro, Demec/PA/Embratel, 1985.

BRASIL, Altino Berthier. Amazônia: reino da fantasia. Porto Alegre, Posenato Arte \& Cultura, 1987.

BRITO, Maria Lenora Menezes de. Uma leitura da música de Waldemar Henrique. Belém, Conselho Estadual de Cultura, 1986 (Coleção “Cultura Paraense”, série "Theodoro Braga").

CLAVER FILHO, José. Waldemar Henrique: o canto da Amazônia. Rio de Janeiro, Funarte, 1978 (Coleção MPB, 2).

COSTA, Maria José Jackson (org.). Sociologia na Amazônia: debates teóricos e experiências de pesquisa. Belém, Universidade Federal do Pará, 2001.

GODINHO, Sebastião. Waldemar Henrique da Costa Pereira. Belém, Secretaria de Estado da Cultura do Pará, Gráfica Falângola, 1994.

HENRIQUE, Waldemar. Canções - Ensaio de Vicente Salles. Belém, Secretaria de Estado de Educação/ Fundação Carlos Gomes, 1996.

. Só Deus sabe porque. Belém, Gráfica Falângola, 1989.

IGAYARA, Susana Cecília. "Sobre a composição do Combatimento di Tancredi e Clorinda e a Definição do Stile Concitato". Revista Música, São Paulo, n. 9 e 10, 1999, pp. 7791 .

LOUREIRO, João de Jesus Paes. Cultura amazônica. Uma poética do imaginário. Belém, Cejup, 1995.

MELLO, Nazaré. Contos infantis: lendas amazônicas. Belém, Nazaré Mello, 2001.

MIRANDA, Ronaldo. Waldemar Henrique: compositor brasileiro. Belém, Falângola, 1979. 
MONTEIRO, Vanildo. Ritmos paraenses: registro musical de 9 manifestações folclóricas. Trabalho de Conclusão de Curso de Graduação. Belém, Centro de Ciências Sociais e Educação, s/d.

MONTEIRO, Walcyr. "Nossas lendas". Revista Nosso Pará. s/n, Belém, set. 1997, pp. 26-35.

OLIVEIRA, Alfredo. Ritmos e cantares. Belém, Secretaria de Cultura, 2000.

OLIVEIRA, José Coutinho de. Folclore amazônico - Lendas. vol. 1. Belém, São José, 1951.

PEREIRA, João Carlos. Encontro com Waldemar Henrique. Belém, Semec, 1984.

PESSOA, Antônio Edvandro; BOGÉA, José Arthur; AZEVEDO, Cláudia Velasco; PEREIRA, João Carlos e JACOB, Maria Célia. "Destaque: Waldemar Henrique”. Revista Asas da Palavra. Belém, Unama, n. 1, jan.-jun. 1994, pp. 6-42.

ROCQUE, Carlos. Antologia da cultura amazônica. Belém, Amazônia Edições Culturais Ltda. (Amada), 1971. 1968

Grande Enciclopédia da Amazônia. Belém, Amazônia Editora Ltda. (Amel),

SALLES, Vicente. A música e o tempo no Grão-Pará. Belém, Conselho Estadual de Cultura, 1980 (Coleção “Cultura Paraense”, série “Theodoro Braga”).

. Música e músicos do Pará. Belém, Conselho Estadual de Cultura, 1970 (Coleção

"Cultura Paraense", série "Theodoro Braga”).

SILVA, Marlene de Deus Tavares da e CAMPOS, Ademar da Silva. Estudos amazônicos.

O Pará em questão. $2^{\underline{a}}$ ed. rev. atual., Belém/ Rio de Janeiro, Fundação Biblioteca Nacional, reg. 167.494/ Ministério da Cultura.

SIMÕES, Maria do Socorro e GOLDER, Christophe. Abaetetuba conta... - Narrativas, recriações. Belém, Cejup/ UFPA, 1995a (Série “Pará Conta”, 3).

. Belém conta... - Narrativas, recriações, depoimentos. Belém, Cejup, 1995b (Série

"Pará Conta", 2).

Santarém conta... - Narrativas, recriações, depoimentos. Belém, Cejup/ UFPA, 1995c (Série "Pará Conta”, 1).

RESUMO - ESTE TEXTO foi extraído de dissertação homônica. Apresenta análise do texto musical e literário de sete obras para canto e piano do compositor paraense Waldemar Henrique, seguida de reflexão sobre as principais características identificadas. O objetivo é oferecer bases para a prática interpretativa fundamentada na composição musical contextualizada dessas obras.

Palavras-chave: Música; Pará; intepretação.

ABSTRACT - THIS ESSAY is an excerpt from a homonymous dissertation and includes analyses of the musical and literary texts of seven pieces for voice and piano by Pará- 
born composer Waldermar Henrique, followed by considerations of their major identified characteristics. The goal is to provide foundations for an interpretative practice based on a contextualized musical understanding of these works.

Key-words: Music; Pará, interpretation.

Márcia Jorge Aliverti é professora de Canto Lírico e Canto Popular da Escola de Música da Universidade Federal do Pará (UFPA) e mestre em Musicologia pelo Programa de Pós-Graduação em Artes da Universidade de São Paulo.

@ - marcialiverti@amazonline.com.br

Texto publicado originalmente em VIEIRA, Lia Braga e IAZZETA, Fernando (orgs.). Trilha da música, Belém, Editora da UFPA, 2004, pp. 121-162.

Recebido em 14/3/2005 e aceito em 18/4/2005. 